\title{
BCR-ABL Tyrosine Kinase Inhibitors as Candidates for the Treatment of COVID-19: Molecular Docking, Pharmacophore Modeling, ADMET Studies
}

\author{
Mohamed S. Attia ${ }^{1}$, Mohammed Y. Hassaballah ${ }^{2}$, Ahmed Negida ${ }^{3}$, Mahmoud M. Sebaiy ${ }^{4 *}$ (D), Noha I. \\ Ziedan ${ }^{5}$ * (D)
}

1 Department of Pharmaceutics, Faculty of Pharmacy, Zagazig University, Zagazig, 44519, Egypt; mosalahnabet@gmail.com (M.S.A.);

2 Faculty of Pharmacy, Zagazig University, Zagazig, 44519, Egypt; 14129@ stemegypt.edu.eg (M.Y.H.);

3 Zagazig University Hospitals, Zagazig University, Zagazig, Egypt; ahmed.said.negida@ gmail.com (A.N.);

4 Department of Medicinal Chemistry, Faculty of Pharmacy, Zagazig University, Sharkia, 44519, Egypt; mmsebaiy@zu.edu.eg, sebaiym@gmail.com (M.M.S.);

5 Department of Mathematical and Physical sciences, Faculty of Science and Engineering, University of Chester, $\mathrm{CH} 2$ 4NU, Kingdom; n.ziedan@chester.ac.uk (N.I.Z.);

* Correspondence: mmsebaiy@ zu.edu.eg, sebaiym@gmail.com (M.M.S.);.n.ziedan@ chester.ac.uk (N.I.Z.); .

Received: 30.01.2021; Revised: 30.4.2021; Accepted: 10.05.2021; Published: 8.08.2021

\begin{abstract}
The novel coronavirus pandemic (COVID-19) caused by SARS-CoV-2 has affected more than 53 million individuals worldwide. Currently, there is a dire need to develop or find potential drugs that can treat SARS-CoV-2 infection. One of the standard methods to accelerate drug discovery and development in pandemics is to screen currently available medications against the critical therapeutic targets to find potential therapeutic agents. The literature has pointed out the $3 \mathrm{CL}^{\text {pro }}$ and $\mathrm{RdRp}$ proteins as the most important proteins involved in viral replications. In the present study, we used an in-silico modeling approach to examine the affinity of six tyrosine kinases inhibitors (TKIs), Imatinib, Ponatinib, Nilotinib, Gefitinib, Erlotinib, and Dasatinibagainst the $3 \mathrm{CL}^{\text {pro }}$ and RdRp by calculating the energy balance. The six tested TKIs had more than $-7 \mathrm{Kcal} / \mathrm{mol}$ energy balance values for both viral target proteins. Nilotinib and Ponatinib showed the highest affinity for $3 \mathrm{CL}^{\text {pro }}(-8.32,-8.16$, respectively) while Dasatinib, Ponatinib, and Imatinib presented the strongest binding toRdRp(-14.50, -10.57, -9.46, respectively). Based on these findings, we recommend future evaluations of TKIs for SARs-CoV-2 infection in-vitro and further testing in clinical trials.
\end{abstract}

Keywords: COVID-19; tyrosine kinase; RdRp; 3CL ${ }^{\text {pro }}$; molecular docking.

(c) 2021 by the authors. This article is an open-access article distributed under the terms and conditions of the Creative Commons Attribution (CC BY) license (https://creativecommons.org/licenses/by/4.0/).

\section{Introduction}

The recent novel coronavirus disease pandemic (COVID-19) has affected more than 53 million individuals worldwide. There is a lack of antiviral agents that can provide pharmacological viral clearance of the SARS-CoV-2 infection. The recently approved Remedesivir was found to accelerate the recovery but with no impact on patient survival. Also, the recent findings on Dexamethasone clinical trials suggest a clinical benefit for the subset of patients requiring oxygen supplementation and those in the ICU with a lack of benefit for the subgroup of patients with mild and moderate infections [1].

Consequently, the mortality rates of SARS-CoV-2 are still substantial in light of the explosive and rapid spread of the virus. There is an unmet clinical need to find potent antiviral 
treatments that can inhibit virus replication and translate to better clinical outcomes and lower mortality rates among infected individuals.

Results of many sequence alignment studies have shown that 3CLpro was highly conserved with $100 \%$ identity in all SARS-CoV-2 genomes examined [2,3]. The protein sequence of SARS-CoV-2 3CLpro with the protein sequence of 3CLpro of the other homologs (Bat-CoV, SARS-CoV, MERS-CoV, Human-CoV, and Bovine-CoV) [3,4]. According to the comparison, 3CLpro clusters of Bat-Cov shares $99.02 \%$ with those of SARS-Cov-2. Furthermore, SARS-Cov-2 3CLpro shares $96.08 \%, 87 \%, 90 \%$, and 90\% sequence identity with SARS-CoV, MERS-CoV, Human-CoV, and Bovine-CoV homologs, respectively [2,4,5]. These findings imply that SARS-CoV-2 has a higher similarity with SARS-CoV than MERS$\mathrm{CoV}$ and shares a common ancestor with Bat-CoV. Although the similarity of SARS-CoV to SARS-CoV-2 is very high, there are variations at 12 different positions in the sequence of (residues numbers 33, 44, 63, 84 86, 92, 132, 178, 200, 265, 283, and 284) [6,7]. The physiochemical characteristics of 3CLpro revealed that it has a polypeptide chain of 306 amino acids and a molecular weight of 33,796.64 Da [2]. RNA-dependent RNA polymerase (RdRp) is a conserved protein called Nsp12, which is a vital enzyme for the replication and transcription of SARS-CoV-2. In previous research, it was found that Nsp12-RdRp has been used as a significant drug target. Inhibition of Nsp12 does not cause significant toxicity on host cells, while it can kill SARS-CoV-2 [8-11].

Being the most critical viral proteins affecting the SARS-CoV-2 replication cycle, the 3CLpro and RdRp were used for this in-silico modeling to study the potential of TKIs in inhibiting SARS-CoV-2 replication. The rationale for examining TKIs for these targets could be explained as follows [12].

First of all, several TKIs that possess anticancer activity have recently shown broadspectrum in-vitro activity against HCV, HIV, SARS-CoV, MERS-CoV, DENV, and EBOV [13-17]. The underlying antiviral mechanism of TKIs could not be attributed to a specific pathway since TKIs do not possess an equal affinity to all the kinases but for only one to three kinases.

Second, COVID-19 uses ACE-2 receptors on the cell surface to enter lung alveolar type II (AT2) epithelial cells through spikes, which are prior activated by extracellular proteases, including transmembrane protease serine 2 (TMPRSS2) [18-20]. Bcr-Abl tyrosine kinase inhibitors would block multiples pathways associated with cell differentiation and proliferation, which is anticipated to reduce ACE-2 levels in epithelia. Consequently, yielding immature cells expressing a low level of ACE-2 makes them theoretically less vulnerable to infection [21-23]. Side to side with the fact that ABL1 inhibitors such as Nilotinib \& ponatinib were found to combat cytokine storm seen in lethal influenza infection, resulting in higher survival rates of infected mice. This effect is believed to be effective in reducing the mortality of SARS-Cov-2 [24,25]. While inhibitors of Adaptor-associated protein kinase 1 (AAK1) and Cyclin G-associated kinase (GAK) such as erlotinib \& sunitinib, which are activating protein 2 (AP2) regulators that modulate ACE-2 induced clathrin endocytosis, which is considered a central point in the virion entry mechanism [26-33].

Third, Fyn kinase was found to play a role in dengue virus RNA replication [34-37]. It was also reported to be associated with the activation of NF- $\kappa \mathrm{B}$, which is responsible for the expression of cytokines in response to interferon signaling, resulting in its inflammatory response observed in neural cells [38-41]. An Inhibitor of Fyn kinase, such as Dasatinib, was repurposed to treat SARS-CoV because it inhibited SARS-CoV in-vitro with EC50 $=2.1 \mu \mathrm{M}$ 
and MERs-CoV with EC50=5.47 $\mu \mathrm{M}$. At this level, the drug is considered non-cytotoxic $[21,42]$. However, dasatinib activity against SARS-CoV suggests that there are other subtle undiscovered mechanisms.

As such, we will shed light on the accessibility of such TKIs as a possible treatment for COVID-19 through drug modeling studies on non-structural protein targets in the virus-like RNA-dependent RNA polymerase (RdRp) and chymotrypsin-like protease (3CLpro).

\section{Materials and Methods}

\subsection{Protein data preparation.}

MOE docking approach against both enzymes 3CLpro and RdRp was applied to predict the degree of inhibition of SARS-CoV-2 by approved anticancer medications. Proteins in PDB format were downloaded from Brookhaven Protein Data Bank (www.rcsb.org/pdb), and the binding sites were generated from the co-crystallized ligand within crystal protein. At first, water molecules were removed from the complex. Then, crystallographic disorders and unfilled valence atoms were corrected using protein report, utility, and clean protein options. Afterward, protein energy was minimized by applying CHARMM [43-45] and Amber14: HT force fields [46].

\subsection{Optimization and data preparation of TKIs.}

An MMFF94X force field. The energy minimization was first implemented to the tested compounds. These compounds were then adjusted for charges, and potential energy and other parameters were controlled by MMFF94 forcefield. The minimized structures were prepared for docking using MOE.

Table 1. The selected TKIs for the molecular modeling process.

\begin{tabular}{|c|c|c|c|c|}
\hline Name & IUPAC name & $\begin{array}{l}\text { PubChem } \\
\text { CID }\end{array}$ & $\begin{array}{c}\text { Molar } \\
\text { mass }\end{array}$ & Formula \\
\hline Imatinib & $\begin{array}{l}\text { (4-methylpiperazin-1-yl)methyl]-N-[4-methyl-3-[(4- } \\
\text { pyridin-3-ylpyrimidin-2-yl)amino]phenyl] benzamide }\end{array}$ & 5291 & 493.6 & $\mathrm{C}_{29} \mathrm{H}_{31} \mathrm{~N}_{7} \mathrm{O}$ \\
\hline Nilotinib & $\begin{array}{l}\text { 4-methyl-N-[3-(4-methylimidazol-1-yl)-5- } \\
\text { (trifluoromethyl)phenyl]-3-[(4-pyridin-3-ylpyrimidin-2- } \\
\text { yl)amino] benzamide }\end{array}$ & 644241 & 529.5 & $\mathrm{C}_{28} \mathrm{H}_{22} \mathrm{~F}_{3} \mathrm{~N}_{7} \mathrm{O}$ \\
\hline Dasatinib & $\begin{array}{l}\text { N-(2-chloro-6-methylphenyl)-2-[[6-[4-(2- } \\
\text { hydroxyethyl)piperazin-1-yl]-2-methylpyrimidin-4- } \\
\text { yl]amino]-1,3-thiazole-5-carboxamide }\end{array}$ & 3062316 & 488 & $\mathrm{C}_{22} \mathrm{H}_{26} \mathrm{ClN}_{7} \mathrm{O}_{2} \mathrm{~S}$ \\
\hline Ponatinib & $\begin{array}{l}\text { 3-(2-imidazo[1,2-b]pyridazin-3-ylethynyl)-4-methyl-N- } \\
\text { [4-[(4-methylpiperazin-1-yl)methyl]-3- } \\
\text { (trifluoromethyl)phenyl]benzamide }\end{array}$ & 24826799 & 532.6 & $\mathrm{C}_{29} \mathrm{H}_{27} \mathrm{~F}_{3} \mathrm{~N}_{6} \mathrm{O}$ \\
\hline Gefitinib & $\begin{array}{l}\text { N-(3-chloro-4-fluorophenyl)-7-methoxy-6-(3-morpholin- } \\
\text { 4-ylpropoxy)quinazolin-4-amine }\end{array}$ & 123631 & 446.9 & $\mathrm{C}_{22} \mathrm{H}_{24} \mathrm{ClFN}_{4} \mathrm{O}_{3}$ \\
\hline Erlotinib & $\begin{array}{l}\mathrm{N}-(3-\text {-ethynylphenyl)-6,7-bis }(2- \\
\text { methoxyethoxy)quinazolin-4-amine }\end{array}$ & 176870 & 393.4 & $\mathrm{C}_{22} \mathrm{H}_{23} \mathrm{~N}_{3} \mathrm{O}_{4}$ \\
\hline
\end{tabular}

The defined pocket was taken as the active site and extended to $6.5 \AA$ to include all putative active site residues. Triangle matcher was chosen as the placement methodology, London $\mathrm{dG}$, as the scoring function. The receptor was held rigid, while the ligands were allowed to be flexible during the refinement. Each molecule was allowed to produce five different interaction poses with the protein. GBVI/WSA dG was used as a scoring function during refinement. The docking scores of the best-fitted poses with the active site at both protein sites were recorded. We used all these processes to predict the proposed binding mode, 
affinity, preferred orientation of each docking pose, and binding Free energy $(\Delta G)$ of the tested compounds with RdRp.

\subsection{Pharmacophore modeling.}

The protein co-crystallized with the ligand was loaded into MOE (PDB code: 7b2v) and prepared using Amber10 forcefield. The interaction between the ligand and the protein was visually inspected. The electrostatic map for the active site was created, and the pharmacophore query was created using the pharmacophore query editor. The program created annotation points, which were used to select the most relevant features. After feature selection, the volume feature was added to only include the volume occupied by the active ligand. The model created was then tested against all 6 compounds allowing the partial matching of a minimum of 4 features and keeping a minimum of 1 aromatic feature and $1 \mathrm{H}$-acceptor feature.

\subsection{ADMET analysis.}

The prediction of pharmacokinetics, potential toxicities, and carcinogenicity of each drug was carried through the AdmetSAR2 database [47,48].

\section{Results}

\subsection{Structure of target proteins.}

The main therapeutic targets for SARS-CoV-2 used for the study were $3 \mathrm{CL}^{\text {pro }}$ and RdRp. The three-dimensional structures of these proteins were obtained from the protein data bank (PDB ID: 6y2f, resolution 1.95) [49] and (PDB ID: 7bv2, resolution 2.50) [50,51], respectively.

Table 2. Energy Balances of TKIs-RdRp, and TKIs-3Clpro $(\mathrm{Kcal} / \mathrm{mol})$.

\begin{tabular}{|c|c|c|c|c|c|c|c|c|c|c|c|c|}
\hline \multirow[t]{2}{*}{ Drug } & \multicolumn{6}{|c|}{ Energy Balance of TKIs-RdRp (Kcal/mol) } & \multicolumn{6}{|c|}{ Energy Balance of TKIs-3Clpro $(\mathrm{Kcal} / \mathrm{mol})$} \\
\hline & $\mathbf{S}$ & $\begin{array}{c}\text { Rmsd } \\
- \\
\text { refine }\end{array}$ & $\begin{array}{c}\text { E- } \\
\text { Conf }\end{array}$ & $\begin{array}{c}\text { E- } \\
\text { Place }\end{array}$ & $\begin{array}{c}\text { E- } \\
\text { Score1 }\end{array}$ & $\begin{array}{c}\text { E- } \\
\text { Refine }\end{array}$ & $\mathbf{S}$ & $\begin{array}{c}\text { Rms } \\
\text { d- } \\
\text { refin } \\
\text { e }\end{array}$ & $\begin{array}{c}\text { E- } \\
\text { Conf }\end{array}$ & $\begin{array}{c}\text { E- } \\
\text { Place }\end{array}$ & $\begin{array}{c}\text { E- } \\
\text { Score1 }\end{array}$ & $\begin{array}{c}\text { E- } \\
\text { Refine }\end{array}$ \\
\hline Ligand & -11.05 & 1.39 & $\begin{array}{c}- \\
139.2 \\
6 \\
\end{array}$ & -61.41 & -16.08 & $\begin{array}{c}- \\
118.83\end{array}$ & $\begin{array}{c}- \\
9.04\end{array}$ & 2.23 & 67.07 & -83.64 & -9.26 & -50.21 \\
\hline Dasatinib & -14.50 & 1.44 & $\begin{array}{c}- \\
187.8 \\
4\end{array}$ & -31.86 & -21.98 & $\begin{array}{c}- \\
179.92\end{array}$ & $\begin{array}{c}- \\
7.67\end{array}$ & 2.08 & $\begin{array}{c}- \\
197.5 \\
1\end{array}$ & -96.80 & $\begin{array}{c}- \\
10.511\end{array}$ & -44.69 \\
\hline Ponatinib & -10.57 & 3.38 & $\begin{array}{c}145.0 \\
5\end{array}$ & -46.23 & -8.95 & $\begin{array}{c}- \\
125.22\end{array}$ & $\begin{array}{c}- \\
8.16\end{array}$ & 1.68 & $\begin{array}{c}141.5 \\
8\end{array}$ & $\begin{array}{c}- \\
110.7 \\
8\end{array}$ & -9.94 & -46.89 \\
\hline Imatinib & -9.46 & 2.12 & -27.27 & $\begin{array}{c}- \\
101.1 \\
3 \\
\end{array}$ & -10.46 & -97.57 & $\begin{array}{c}- \\
7.74\end{array}$ & 2.28 & -14.32 & -87.82 & -10.21 & -48.90 \\
\hline Nilotinib & -7.45 & 2.64 & -59.54 & -44.72 & -9.49 & -38.71 & $\begin{array}{c}- \\
8.32 \\
\end{array}$ & 1.76 & -58.36 & -96.77 & -12.47 & -48.32 \\
\hline Gefitinib & -7.82 & 5.38 & -0.29 & -82.17 & -10.20 & -82.51 & $\begin{array}{c}- \\
7.55\end{array}$ & 2.20 & -3.65 & -63.91 & -9.81 & -46.55 \\
\hline Erlotinib & -8.92 & 3.20 & -33.14 & -36.40 & -10.30 & -99.58 & $\begin{array}{c}- \\
7.83\end{array}$ & 1.70 & -31.70 & -90.06 & -10.33 & -49.21 \\
\hline
\end{tabular}

The $3 \mathrm{CL}^{\text {pro }}$ model was predicted and designed as a homo-dimer with both protomers. Those protomers are oriented at almost right angles to each other and labeled as ' $A$ ' and ' $\mathrm{B}$ '. The single monomer was found to be composed of three different globular domains. Domain I and II form a substrate-binding site, which is formed of a Cys145-His41 catalytic dyad. The 
composition of the substrate-binding pocket is His41, Phe140, Asn142, Gly143, Ser144, Cys145, Tyr161, His163, Glu166, and His172 residues [52-55]. The interaction of the crystal ligand within the binding pocket of $3 \mathrm{CL}^{\text {pro }}$ is shown in figure1-A.

\subsection{Energy Balance for RdRp and $3 C L^{\text {pro }}$ with TKIs}

$\mathrm{S}$ : the final score; is the score of the last step, Rmsd-refine: the mean square deviation between the laying before refinement and after refinement pose, E-Conf: energy conformer, EPlace: score of the placement phase, E-Score1: score the first step of notation, E-refine: score refinement step and the number of conformations generated by ligand [56,57].

\section{Discussion}

\subsection{Summary of study findings.}

This study showed that TKIs might hold a promise for the treatment of SARS-CoV-2 infection. The examined compounds (Dasatinib, Imatinib, Nilotinib, Erlotinib, Ponatinib, and Gefitinib) showed substantial affinity to $3 \mathrm{CL}^{\text {pro }}$ and RdRP, which have a pivotal role in the SARS-CoV-2 replication cycle [58,59]. Notably, Dasatinib, Ponatinib, and Imatinib showed the highest scores for the inhibition of RdRp, while Ponatinib and Nilotinib were presented as potential inhibitors of $3 \mathrm{CL}^{\text {pro }}$.

\subsection{Explanation of the study results.}

\subsubsection{RNA-dependent RNA polymerase (RdRp).}

The sequence identity percentage between SARS-CoV-2 RdRp and SARS, MERS, OC43, NL63, 229E, , HKU1 and HCoV strains were found to be 90.18\%, 56.76\%, 55.07\%, $48.79 \%, 48.55 \%$, and $48.16 \%$, respectively. These findings revealed that the SARS-CoVRdRp is the closest strain to the SARS-CoV-2 RdRp [60-63].

Dasatinib has shown an excellent binding capacity to the RdRp enzyme with an affinity of $-14.5 \mathrm{kcal} / \mathrm{mol}$, as shown in Table 2. Compared to crystal ligand, Dasatinib showed a comparatively higher affinity, which equals $(-11.05) \mathrm{kcal} / \mathrm{mol}$. Dasatinib has also presented a low Root-mean-square deviation (RSMD) of $1.44 \AA$, which is smaller than the ligand, making the binding more stable with lower rotations. These results are illustrated by three main types of interactions between Dasatinib and RdRp: electrostatic, hydrophobic, and hydrogenbonding interactions. In contrast, the ligand binding with RdRp is achieved through two main types of interactions are shown in Figures 1-A\& 2-A. As depicted in Figures 1-G\& 2-G, the pyrimidine moiety of Dasatinib formed arene-H interaction with AB19, while the nitrogen atom of piperazine moiety formed an electrostatic interaction with MG1005. Moreover, the carbonyl group forms a hydrogen bond with both AC11.

Imatinib score showed that it would bind with plausible binding energy to SARS-COV$2 \operatorname{RdRp}(-9.46 \mathrm{kcal} / \mathrm{mol})$, which is lower than that of Dasatinibsince it lacks a strong hydrogen bond formed by the carbonyl group in Dasatinib. In comparison to the ligand, Imatinib also showed a fair, binding affinity and lower RSMD, which result in more stable and potent binding to the active sites of RdRp. Five interactions work to stabilize the binding of Imatinib with $\mathrm{RdRp}$. Arene-H interaction was formed between the pyrimidine moiety of Imatinib and AC11. Two H-bonds were created between two nitrogen atom and UC10, while the piperazine moiety interacted electrostatically with MG1005 and MG1004 (Figures 1-B\& 2-B). 
Binding results of RdRp are consistent with the previously reported in-vitro inhibition of SARS-CoV results since Dasatinib showed higher inhibition results than Imatinib. RdRp results suggest that the virus is more liable to RdRp inhibition, and the TKIs might mediate their action on SARS-CoV-2 by inhibiting this target.

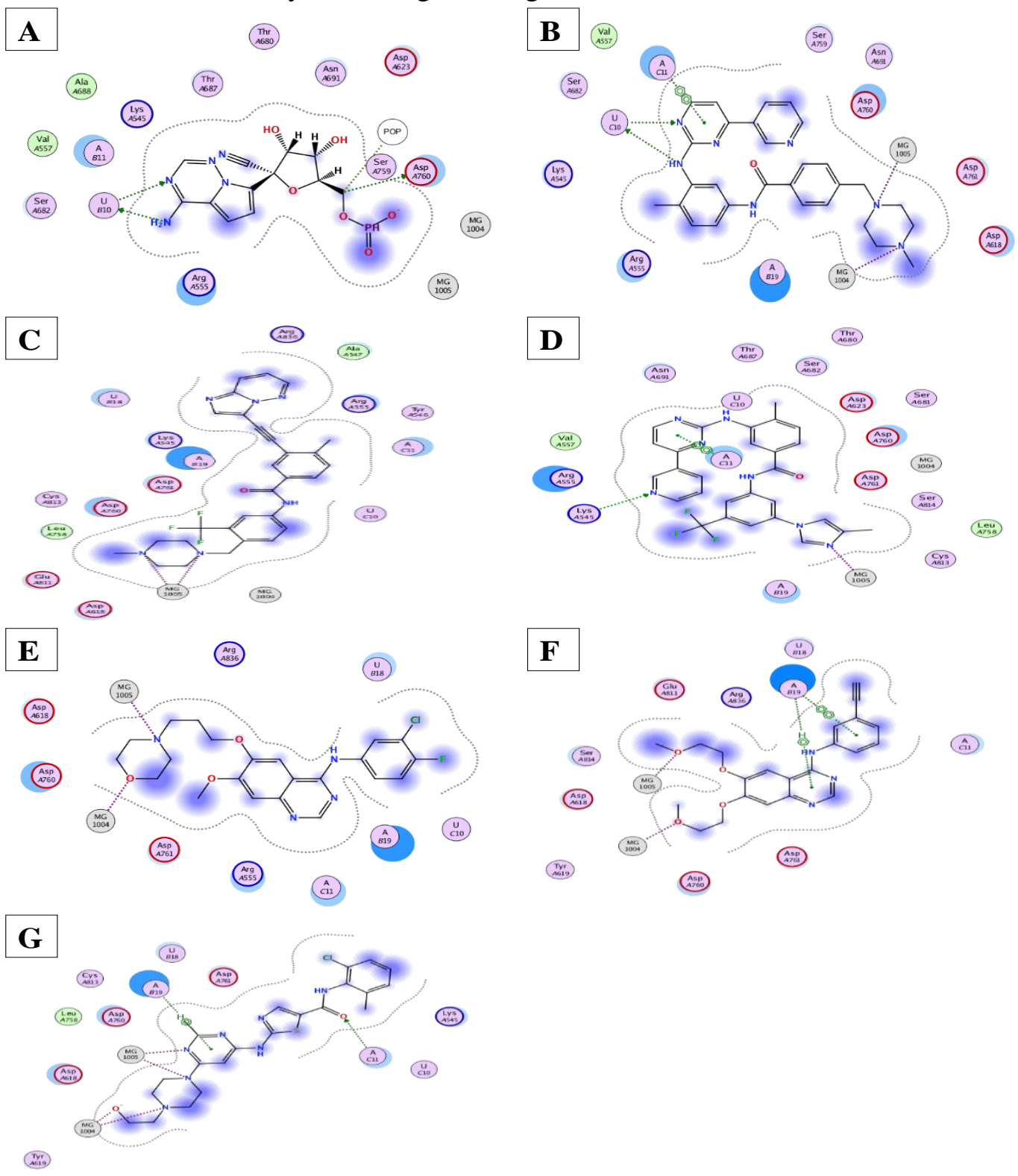

Figure 1. 2D binding mode representation of the binding site of SARS-CoV-2 RdRp with (A) Crystal ligand; (B) Imatinib; (C) Ponatinib; (D) Nilotinib; (E)Gefitinib; (F) Erlotinib; (G) Dasatinib.

\subsubsection{3-Chemotrypsin-Like protease (3CL $\left.{ }^{\mathrm{pro}}\right)$.}

The protein structure of $3 \mathrm{CL}^{\text {pro }}$ could explain these energy balance results is stable, hydrophilic, and can create a hydrogen bond with drugs [64]. This could elucidate the provenaffinity of flavonoids and 3clpro as in apigenin, luteolin, quercetin, quercetin, epigallocatechin, epigallocatechin gallate, gallocatechin gallate, and kaempferol.These compounds were reported to inhibit the proteolytic activity of SARS-CoV 3CL pro mainly through hydrogen bonding and other interactions [65-71].

Results for Nilotinib docking showed relatively higher binding to the $3 \mathrm{CL}^{\text {pro }}$ enzyme with an affinity of $-8.32 \mathrm{kcal} / \mathrm{mol}$, as shown in Table 2 . The azo group of Nilotinib forms an H-bond with Thr26. Another type of interaction was the heterocyclic imidazole that forms pi- 
interaction with Met165. Moreover, the fluorine atom forms an electrostatic interaction with Thr190. Nilotinib also shows a Root-mean-square deviation (RSMD) of 1.76, which is lower than the ligand, making the binding more stable with minor rotations (Figures 3-D \&4-D).
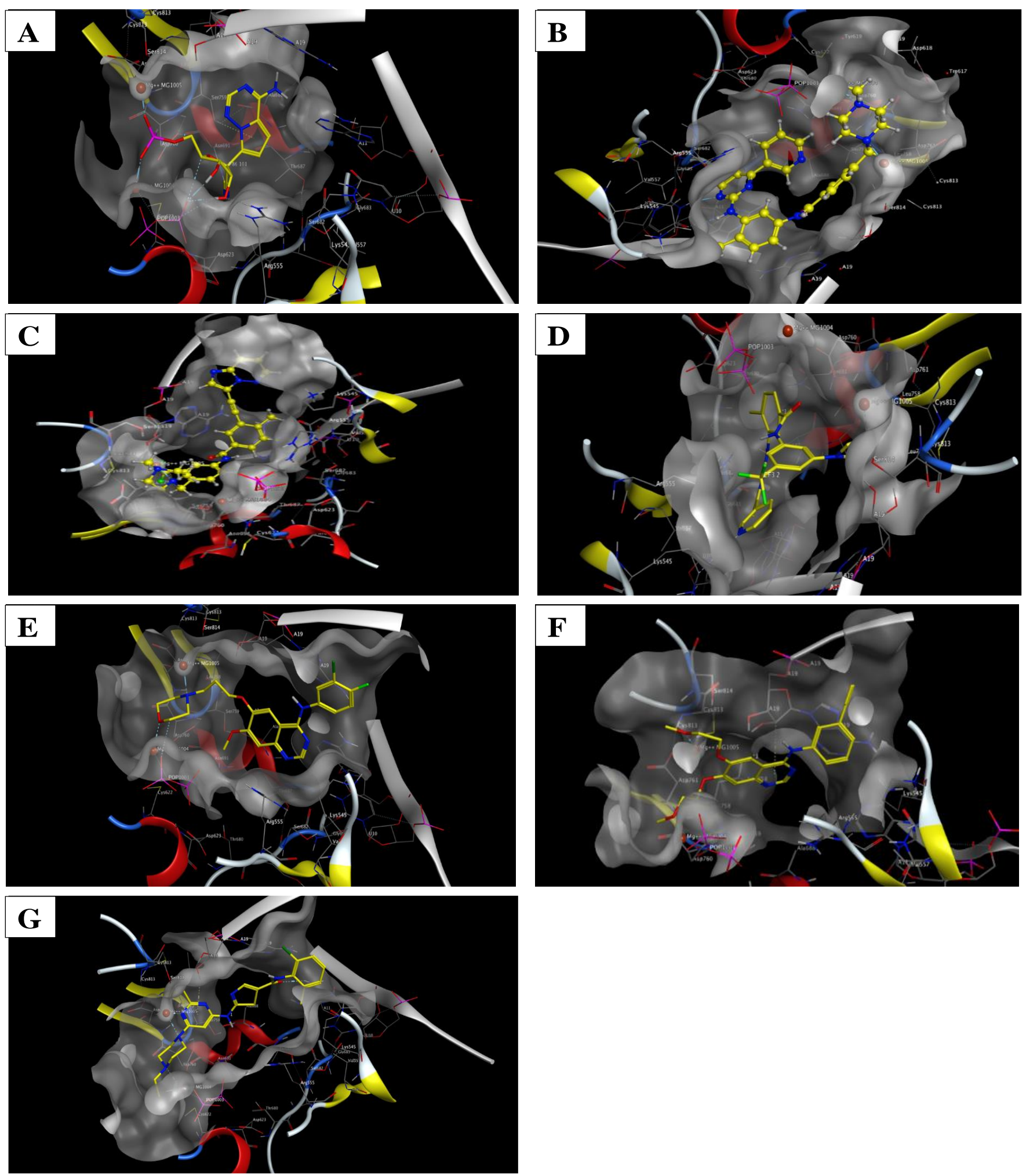

Figure 2. 3D representation of essential amino acid residue of SARS-CoV-2 RdRp binding with (A) Crystal ligand; (B) Imatinib; (C) Ponatinib; (D) Nilotinib; (E)Gefitinib; (F) Erlotinib; (G) Dasatinib.

Ponatinib interaction with the $3 \mathrm{CL}^{\text {pro }}$ enzyme revealed an affinity of $-8.16 \mathrm{kcal} / \mathrm{mol}$, as shown in Table 2. This binding energy is a result of hydrogen-bonding and hydrophobic interactions. The nitrogen atom of ponatinib formed a hydrogen bond with Met49, while 
Ponatinib generated hydrophobic interaction with Thr26. Compared to the ligand, ponatinib showed a reasonable binding affinity and lower RSMD (Figures 3-C\&4-C).

Dasatinib(Figures 3-G \& 4-G) and Imatinib (Figures 3-B \& 4-B) also showed an affinity to $3 \mathrm{CL}^{\text {pro }}$, making them available candidates in the treatment strategy of COVID-19 targeting the $3 \mathrm{CL}^{\mathrm{pro}}$ enzyme hand in hand with the RdRp enzyme.
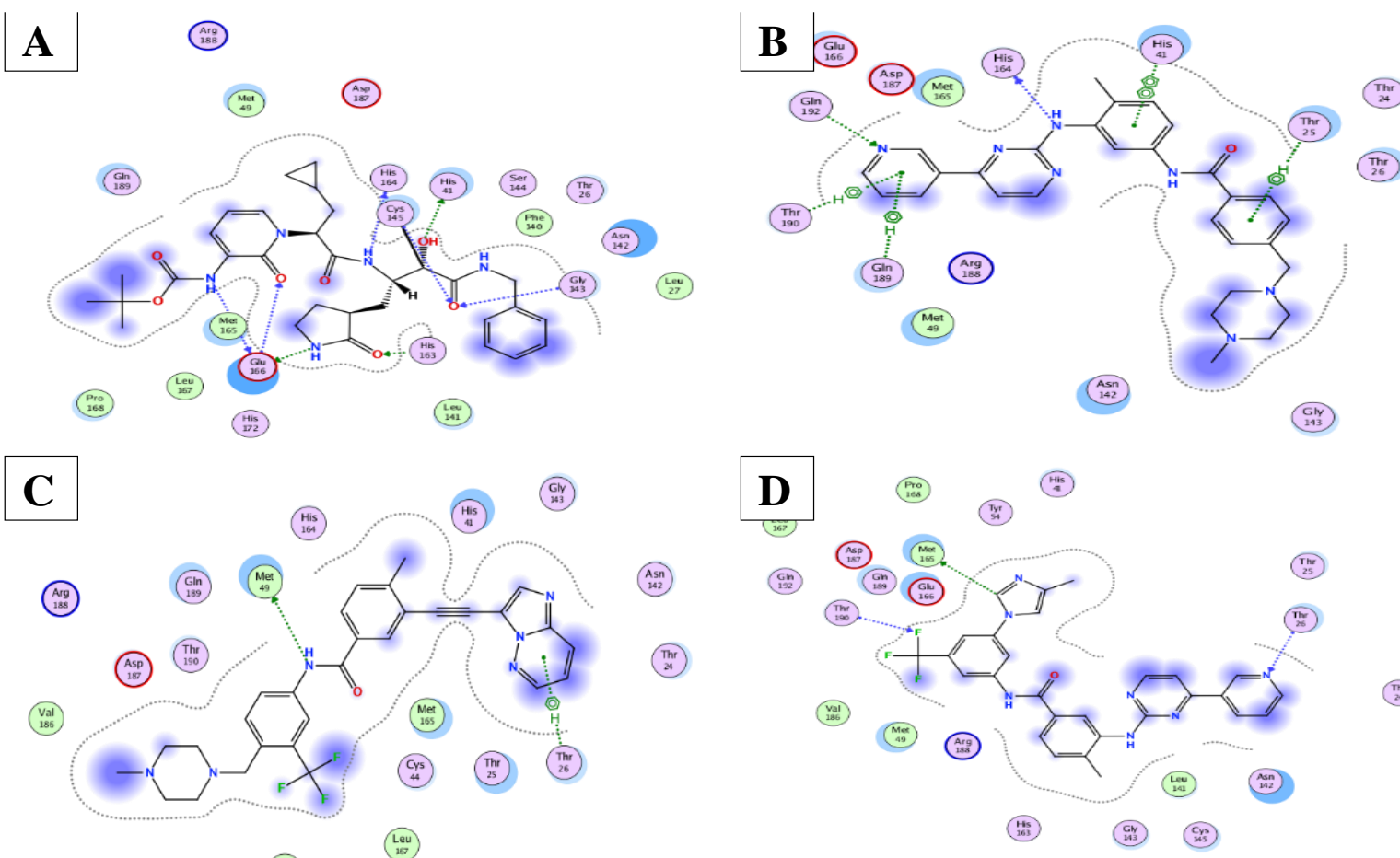

(AsD)

(inir)
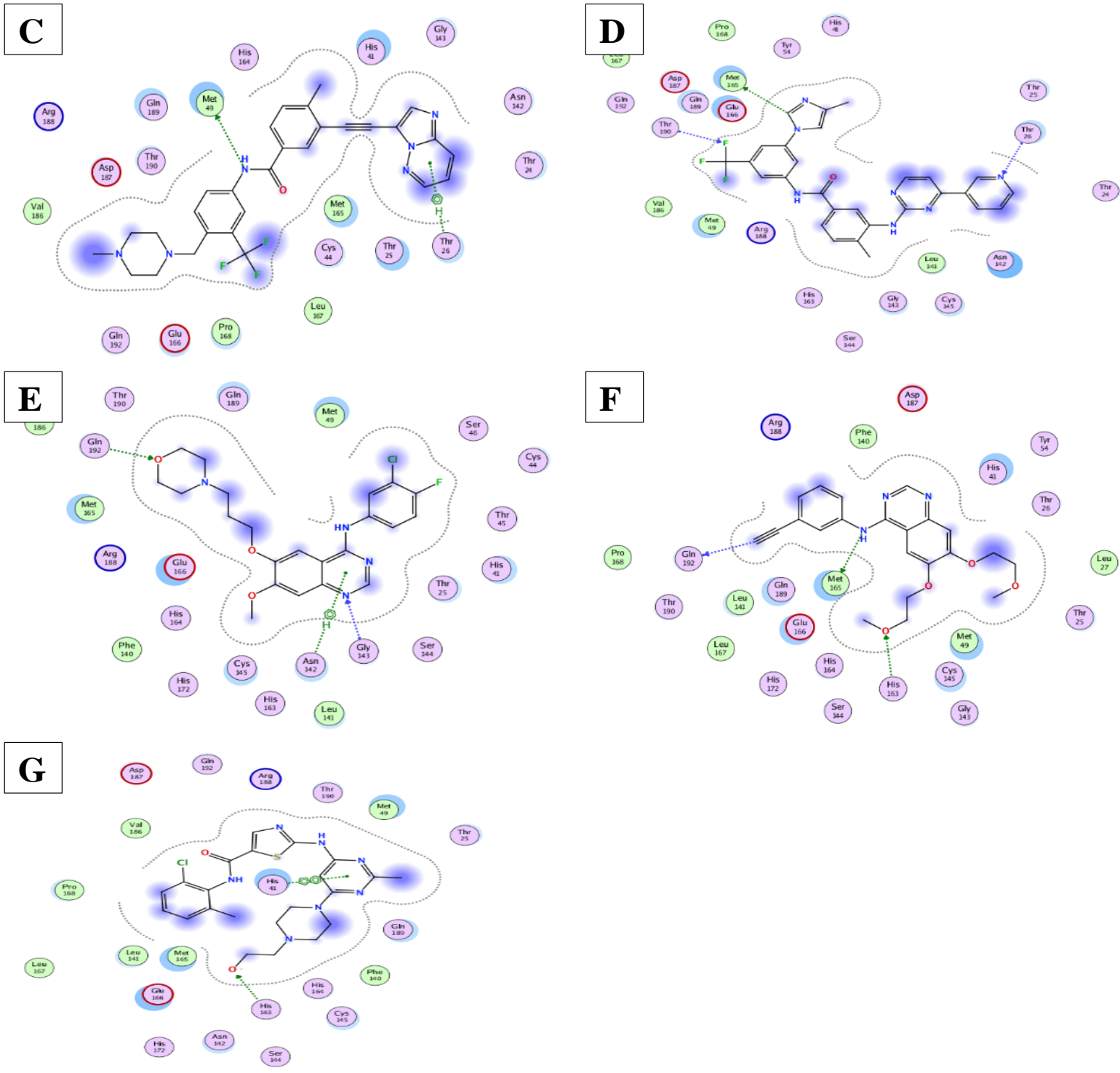

Figure 3. 2D binding mode representation of the binding site of SARS-CoV-2 3CL ${ }^{\text {pro }}$ with (A) Crystal ligand; (B) Imatinib; (C)Ponatinib; (D) Nilotinib; (E)Gefitinib; (F) Erlotinib; (G) Dasatinib. 

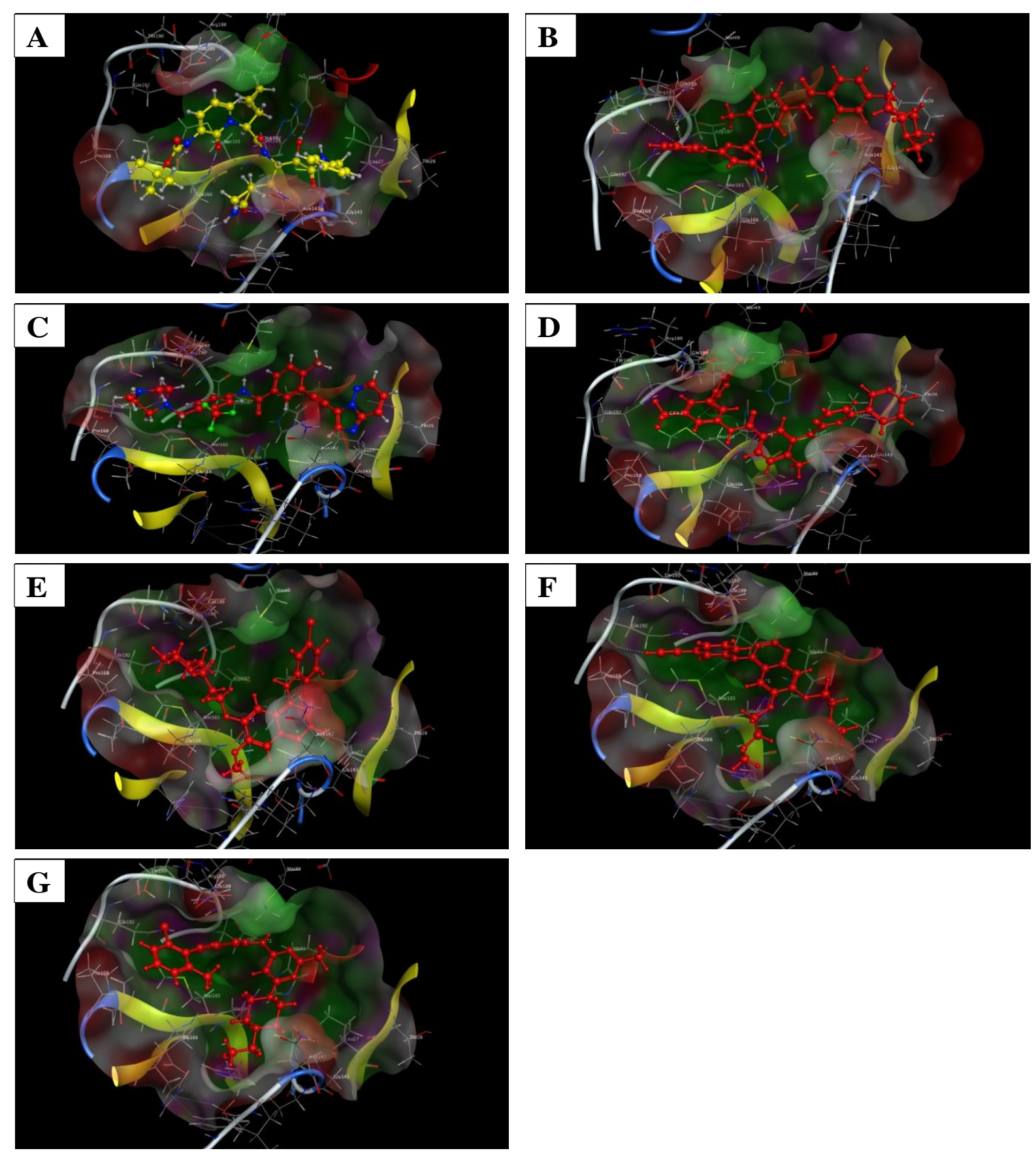

Figure 4. 3D representation of essential amino acid residue of SARS-CoV-2 3CL pro binding with (A) Crystal ligand; (B) Imatinib; (C)Ponatinib; (D) Nilotinib; (E)Gefitinib; (F) Erlotinib; (G) Dasatinib.

\subsection{Pharmacophore query.}

A 3D pharmacophore model was created based on the interaction between the ligand co-crystallized with the protein (PDB code: 7bv2) and the active site analysis. Seven features were derived: as shown in Figure 5, 2 aromatic features (F1 and F5) due to the presence of hydrophobic map at this position, at least one of these must be present, 4 Hydrogen bond acceptors (F2, F4, F6, and F7) reflecting the presence of H-bonds with the protein active site, a constrain was added (at least one of F4 and F6 must be present), and $1 \mathrm{H}$-bond donor (F3). The distance between the features in Angstrom is shown in Figure 5. The created model was tested against the six compounds with a minimum of 4 features, including at least one of F1and F5 aromatic features and F4 and F6 acceptor features. All six compounds matched the pharmacophore query created. 

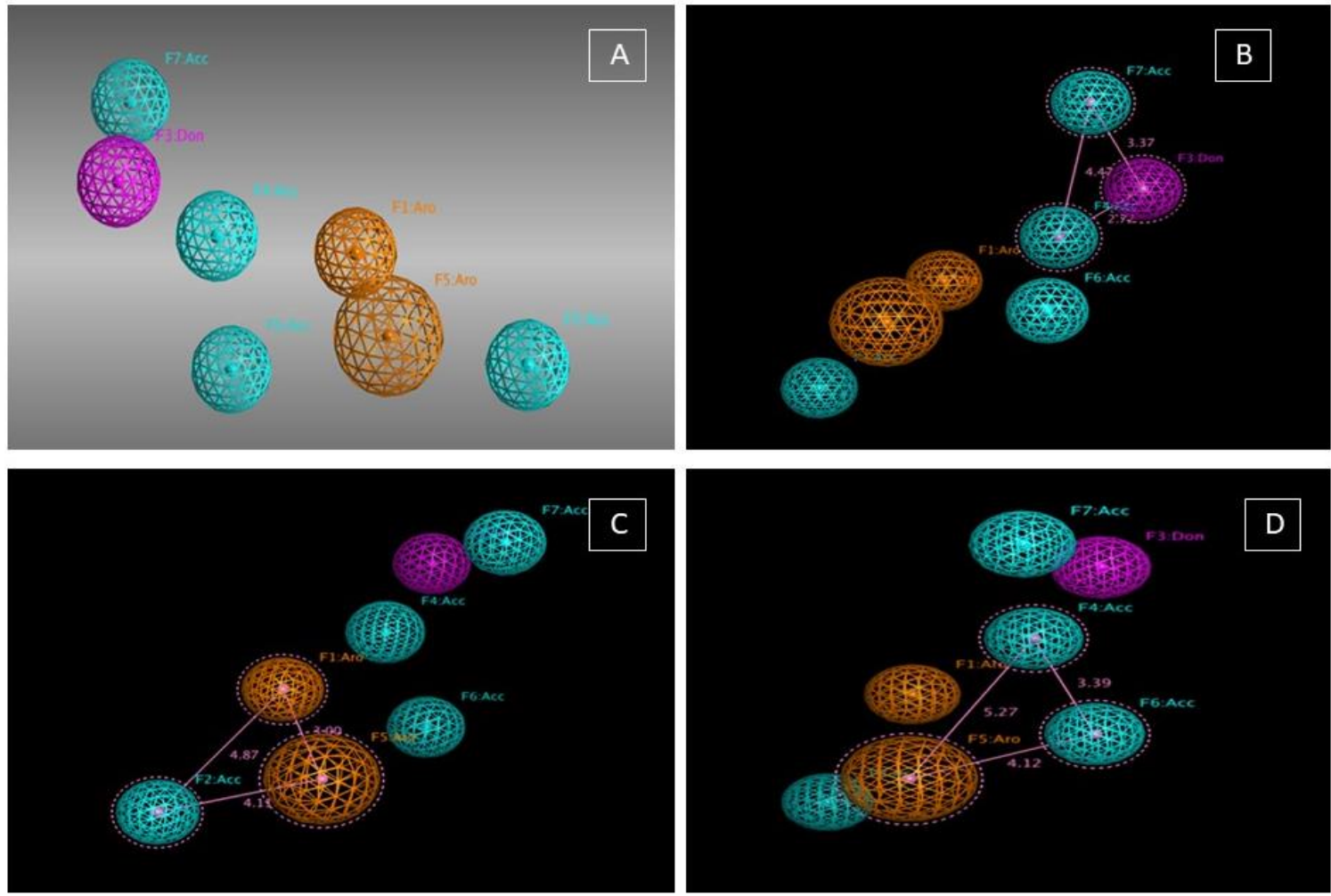

Figure 5. 3D pharmacophoric model for Covid-sars 2 RdRp showing different features of the query A) Representation of different features as F1 and F5: aromatic features, F2, F4, F6, and F7: H-bond acceptors and F3: H-bond donor, B) Distance in Angstrom between F1, F2, and F7, C) Distance in Angstrom between F1, F2, and F5, D) Distance in Angstrom between F4, F5, and F6.

\subsection{ADMET analysis.}

Selected parameters are shown in Table 3. The ADMET analysis provided by admetSAR2 revealed that the six molecules pass the blood-brain barrier (BBB) and intestinal mucosa with a high probability ranging from [(0.96-0.99). (0.93-0.99), respectively. All the mentioned compounds were presented as III category acute oral toxicity; thus, these drugs are anticipated to have low irritation and can be a candidate for transdermal administration.

\begin{tabular}{|c|c|c|c|c|c|c|}
\hline Drug & $\begin{array}{l}\text { Blood-brain } \\
\text { barrier }\end{array}$ & $\begin{array}{l}\text { Human intestinal } \\
\text { absorption }\end{array}$ & P-glycoprotein inhibitor & hERG & $\begin{array}{l}\text { Carcinogen } \\
\text { (binary) }\end{array}$ & $\begin{array}{l}\text { Acute oral } \\
\text { toxicity } \\
(\mathrm{kg} / \mathrm{mol})\end{array}$ \\
\hline Dasatinib & $+(0.96)$ & $+(0.93)$ & $+(0.70)$ & $-(0.72)$ & $-(0.87)$ & $\begin{array}{l}\text { III(0.64) } \\
2.85\end{array}$ \\
\hline Imatinib & $+(0.99)$ & $+(0.98)$ & $+(0.95)$ & $+(0.85)$ & $-(0.71)$ & $\begin{array}{l}\text { III (0.70) } \\
2.766\end{array}$ \\
\hline Nilotinib & $+(0.97)$ & $+(0.96)$ & $+(0.83)$ & $+(0.91)$ & $-(0.71)$ & $\begin{array}{l}\text { III }(0.54) \\
3.413\end{array}$ \\
\hline Ponatinib & $+(0.99)$ & $+(0.96)$ & +0.84 & $+(0.72)$ & $-(0.71)$ & $\begin{array}{l}\text { III (0.61) } \\
3.224\end{array}$ \\
\hline Erlotinib & $+(0.97)$ & $+(0.98)$ & $+(0.92)$ & $+(0.69)$ & $-(0.92)$ & $\begin{array}{l}\text { III (0.69) } \\
2.403\end{array}$ \\
\hline Gefitinib & $+(0.99)$ & $+(0.99)$ & $+(0.88)$ & $+(0.89)$ & $-(0.98)$ & $\begin{array}{l}\text { III }(0.70) \\
2.80\end{array}$ \\
\hline
\end{tabular}

These drugs have excellent absorption and distribution characteristics explained by the possible inhibition of P-glycoprotein that has a significant role in reducing the bioavailability and permeability to certain organs [56]. Moreover, TKIswere was predicted to inhibit the 
human ether-a-go-go-related gene (hERG), but the prediction results were variable since Nilotinib showed the highest inhibition results. Testing inhibition of hERG is essential because it holds the potential to develop long QT syndrome [57].

\subsection{Previous Studies.}

To the best of our knowledge, TKIs were not tested and are not currently being tested in any of the currently ongoing clinical trials of COVID-19. However, previous studies provide a strong rationale for testing those agents in SARS-CoV-2. Dasatinib and Imatinib were evaluated for SARS-CoV-1 in-vitro, and there is a great potential to inhibit the SARS-CoV-2 replication.

\subsection{Recommendations for future research and clinical practice.}

Based on the present findings, we suggest that those agents are potential candidates for SARS-CoV-2 treatment that should be advanced to in-vivo and in-vitro evaluations to further testing through well-designed randomized controlled trials.

\section{Conclusions}

The modeling results presented in this study indicate that the FDA-approved tyrosine kinase inhibitors, Imatinib, Ponatinib, Nilotinib, Gefitinib, Erlotinib, and Dasatinib may inhibit viral replication of SARS-CoV-2. Future experiments are recommended to explore the efficacy of these agents in SARS-CoV-2 infected patients.

\section{Funding}

This research received no external funding.

\section{Acknowledgments}

The authors are thankful to Biorender for creating graphical abstract.

\section{Conflicts of Interest}

The authors declare no conflict of interest.

\section{References}

1. Johnson, R. M.; Vinetz, J. M. Dexamethasone in the Management of Covid-19 2020. BMJ. 2020; 370, doi: https://doi.org/10.1136/bmj.m2648.

2. Xu, X.; Chen, P.; Wang, J.; Feng, J.; Zhou, H.; Li, X.; Zhong, W.; Hao, P. Evolution of the Novel Coronavirus from the Ongoing Wuhan Outbreak and Modeling of Its Spike Protein for Risk of Human Transmission. Sci. China Life Sci. 2020, 63, 457-460, https://doi.org/10.1007/s11427-020-1637-5.

3. Tahir ul Qamar, M.; Alqahtani, S. M.; Alamri, M. A.; Chen, L.-L. Structural Basis of SARS-CoV-2 3CLpro and Anti-COVID-19 Drug Discovery from Medicinal Plants. J. Pharm. Anal. 2020. 10, 313-319, https://doi.org/10.1016/j.jpha.2020.03.009.

4. Zhou, P.; Yang, X.-L.; Wang, X.-G.; Hu, B.; Zhang, L.; Zhang, W.; Si, H.-R.; Zhu, Y.; Li, B.; Huang, C.-L.; Chen, H.-D.; Chen, J.; Luo, Y.; Guo, H.; Jiang, R.-D.; Liu, M.-Q.; Chen, Y.; Shen, X.-R.; Wang, X.; Zheng, X.-S.; Zhao, K.; Chen, Q.-J.; Deng, F.; Liu, L.-L.; Yan, B.; Zhan, F.-X.; Wang, Y.-Y.; Xiao, G.-F.; Shi, Z.L. A Pneumonia Outbreak Associated with a New Coronavirus of Probable Bat Origin. Nature. 2020, 579, 270-273, https://doi.org/10.1038/s41586-020-2012-7. 
5. Zhu, N.; Zhang, D.; Wang, W.; Li, X.; Yang, B.; Song, J.; Zhao, X.; Huang, B.; Shi, W.; Lu, R.; Niu, P.; Zhan, F.; Ma, X.; Wang, D.; Xu, W.; Wu, G.; Gao, G. F.; Tan, W. A Novel Coronavirus from Patients with Pneumonia in China, 2019. N. Engl. J. Med. 2020, 382, 727-733, https://doi.org/10.1056/NEJMoa2001017.

6. Zhang, L.; Lin, D.; Sun, X.; Curth, U.; Drosten, C.; Sauerhering, L.; Becker, S.; Rox, K.; Hilgenfeld, R. Crystal Structure of SARS-CoV-2 Main Protease Provides a Basis for Design of Improved $\alpha$-Ketoamide Inhibitors. Science. 2020, 368, 409-412.

7. Naqvi, A. A. T.; Fatima, K.; Mohammad, T.; Fatima, U.; Singh, I. K.; Singh, A.; Atif, S. M.; Hariprasad, G.; Hasan, G. M.; Hassan, Md. I. Insights into SARS-CoV-2 Genome, Structure, Evolution, Pathogenesis and Therapies: Structural Genomics Approach. Biochim. Biophys. Acta BBA - Mol. Basis Dis. 2020, 1866, 165878, https://doi.org/10.1016/j.bbadis.2020.165878.

8. Wu, C.; Liu, Y.; Yang, Y.; Zhang, P.; Zhong, W.; Wang, Y.; Wang, Q.; Xu, Y.; Li, M.; Li, X.; Zheng, M.; Chen, L.; Li, H. Analysis of Therapeutic Targets for SARS-CoV-2 and Discovery of Potential Drugs by Computational Methods. Acta Pharm. Sin. B. 2020, 10, 766-788, https://doi.org/10.1016/j.apsb.2020.02.008.

9. Joshi, R. S.; Jagdale, S. S.; Bansode, S. B.; Shankar, S. S.; Tellis, M. B.; Pandya, V. K.; Chugh, A.; Giri, A. P.; Kulkarni, M. J. Discovery of Potential Multi-Target-Directed Ligands by Targeting Host-Specific SARSCoV-2 Structurally Conserved Main Protease. J. Biomol. Struct. Dyn. 2020, 0, 1-16, https://doi.org/10.1080/07391102.2020.1760137.

10. Cheng, A.; Zhang, W.; Xie, Y.; Jiang, W.; Arnold, E.; Sarafianos, S. G.; Ding, J. Expression, Purification, and Characterization of SARS Coronavirus RNA Polymerase. Virology. 2005, 335, 165-176, https://doi.org/10.1016/j.virol.2005.02.017.

11. Xu, X.; Liu, Y.; Weiss, S.; Arnold, E.; Sarafianos, S. G.; Ding, J. Molecular Model of SARS Coronavirus Polymerase: Implications for Biochemical Functions and Drug Design. Nucleic Acids Res. 2003, 31, 71177130, https://doi.org/10.1093/nar/gkg916.

12. Coleman, C. M.; Sisk, J. M.; Mingo, R. M.; Nelson, E. A.; White, J. M.; Frieman, M. B. Abelson Kinase Inhibitors Are Potent Inhibitors of Severe Acute Respiratory Syndrome Coronavirus and Middle East Respiratory Syndrome Coronavirus Fusion. J. Virol. 2016, 90, 8924-8933, https://doi.org/10.1128/JVI.01429-16.

13. Hutterer, C.; Milbradt, J.; Hamilton, S.; Zaja, M.; Leban, J.; Henry, C.; Vitt, D.; Steingruber, M.; Sonntag, E.; Zeitträger, I.; Bahsi, H.; Stamminger, T.; Rawlinson, W.; Strobl, S.; Marschall, M. Inhibitors of DualSpecificity Tyrosine Phosphorylation-Regulated Kinases (DYRK) Exert a Strong Anti-Herpesviral Activity. Antiviral Res. 2017, 143, 113-121, https://doi.org/10.1016/j.antiviral.2017.04.003.

14. Kumar, N.; Sharma, N. R.; Ly, H.; Parslow, T. G.; Liang, Y. Receptor Tyrosine Kinase Inhibitors That Block Replication of Influenza A and Other Viruses. Antimicrob. Agents Chemother. 2011, 55, 5553-5559, https://doi.org/10.1128/AAC.00725-11.

15. Kumar, N.; Liang, Y.; Parslow, T. G.; Liang, Y. Receptor Tyrosine Kinase Inhibitors Block Multiple Steps of Influenza A Virus Replication. J. Virol. 2011, 85, 2818-2827, https://doi.org/10.1128/JVI.01969-10.

16. Schor, S.; Einav, S. Repurposing of Kinase Inhibitors as Broad-Spectrum Antiviral Drugs. DNA Cell Biol. 2018, 37, 63-69, https://doi.org/10.1089/dna.2017.4033.

17. Yura, Y.; Kusaka, J.; Tsujimoto, H.; Yoshioka, Y.; Yoshida, H.; Sato, M. Effects of Protein Tyrosine Kinase Inhibitors on the Replication of Herpes Simplex Virus and the Phosphorylation of Viral Proteins. Intervirology 1997, 40, 7-14, https://doi.org/10.1159/000150515.

18. Hoffmann, M.; Kleine-Weber, H.; Schroeder, S.; Krüger, N.; Herrler, T.; Erichsen, S.; Schiergens, T. S.; Herrler, G.; Wu, N.-H.; Nitsche, A. SARS-CoV-2 Cell Entry Depends on ACE2 and TMPRSS2 and Is Blocked by a Clinically Proven Protease Inhibitor. Cell. 2020. 181:271-280.e8, DOI: 10.1016/j.cell.2020.02.052.

19. Lukassen, S.; Chua, R. L.; Trefzer, T.; Kahn, N. C.; Schneider, M. A.; Muley, T.; Winter, H.; Meister, M.; Veith, C.; Boots, A. W.; Hennig, B. P.; Kreuter, M.; Conrad, C.; Eils, R. SARS -CoV-2 Receptor ACE 2 and TMPRSS 2 Are Primarily Expressed in Bronchial Transient Secretory Cells. EMBO J. 2020, 39, https://doi.org/10.15252/embj.20105114.

20. Rabi, F. A.; Al Zoubi, M. S.; Kasasbeh, G. A.; Salameh, D. M.; Al-Nasser, A. D. SARS-CoV-2 and Coronavirus Disease 2019: What We Know So Far. Pathogens 2020, 9, 231, https://doi.org/10.3390/pathogens9030231.

21. Dyall, J.; Coleman, C. M.; Venkataraman, T.; Medicine, J. H.; Holbrook, M. R. et al. Repurposing of Clinically Developed Drugs for Treatment of Middle East Respiratory Syndrome Coronavirus Infection. Antimicrob. Agents Chemother 2014, 58, 4885- 4893, https://doi.org/10.1128/AAC.03036-14. 
22. Jia, H. P.; Look, D. C.; Shi, L.; Hickey, M.; Pewe, L.; Netland, J.; Farzan, M.; Wohlford-lenane, C.; Perlman, S.; Mccray, P. B. ACE2 Receptor Expression and Severe Acute Respiratory Syndrome Coronavirus Infection Depend on Differentiation of Human Airway Epithelia 2005, $79 \quad, \quad 14614-14621$, https://doi.org/10.1128/JVI.79.23.14614.

23. Mulgaonkar, N.; Wang, H.; Mallawarachchi, S.; Ruzek, D.; Martina, B.; Fernando, S. Bcr-Abl Tyrosine Kinase Inhibitor Imatinib as a Potential Drug for COVID-19. bioRxiv. 2020, https://doi.org/10.1101/2020.06.18.158196.

24. Chen, S.; Liu, G.; Chen, J.; Hu, A.; Zhang, L.; Sun, W.; Tang, W.; Liu, C.; Zhang, H.; Ke, C.; Wu, J.; Chen, X. Ponatinib Protects Mice from Lethal Influenza Infection by Suppressing Cytokine Storm. Front. Immunol. 2019, 10, 1338-1352, https://doi.org/10.3389/fimmu.2019.01393.

25. Garcia, G.; Sharma, A.; Ramaiah, A.; Sen, C.; Kohn, D.; Gomperts, B.; Svendsen, C. N.; Damoiseaux, R. D.; Arumugaswami, V. Antiviral Drug Screen of Kinase Inhibitors Identifies Cellular Signaling Pathways Critical for SARS-CoV-2 Replication. bioRxiv. 2020, https://doi.org/10.1101/2020.06.24.150326.

26. Richardson, P.; Griffin, I.; Tucker, C.; Smith, D.; Oechsle, O.; Phelan, A.; Stebbing, J. Baricitinib as Potential Treatment for 2019-NCoV Acute Respiratory Disease. The Lancet. 2020, 395 (10223), e30-e31, https://doi.org/10.1016/S0140-6736(20)30304-4.

27. Bekerman, E.; Neveu, G.; Shulla, A.; Brannan, J.; Pu, S. Y.; Wang, S.; Xiao, F.; Barouch-Bentov, R.; Bakken, R. R.; Mateo, R.; Govero, J.; Nagamine, C. M.; Diamond, M. S.; De Jonghe, S.; Herdewijn, P.; Dye, J. M.; Randall, G.; Einav, S. Anticancer Kinase Inhibitors Impair Intracellular Viral Trafficking and Exert BroadSpectrum Antiviral Effects. J. Clin. Invest. 2017, 127, 1338-1352, https://doi.org/10.1172/JCI89857.

28. Alconada, A.; Bauer, U.; Hoflack, B. A Tyrosine-Based Motif and a Casein Kinase II Phosphorylation Site Regulate the Intracellular Trafficking of the Varicella-Zoster Virus Glycoprotein I, a Protein Localized in the Trans-Golgi Network. EMBO J. 1996, 15, 6096-6110, https://doi.org/10.1002/j.1460-2075.1996.tb00998.x.

29. Fingerhut, A.; von Figura, K.; Höning, S. Binding of AP2 to Sorting Signals Is Modulated by AP2 Phosphorylation. J. Biol. Chem. 2001, 276 , 5476-5482, https://doi.org/10.1074/jbc.M009516200.

30. Lee, D. -w. Depletion of GAK/Auxilin 2 Inhibits Receptor-Mediated Endocytosis and Recruitment of Both Clathrin and Clathrin Adaptors. J. Cell Sci. 2005, 118, 4311-4321. https://doi.org/10.1242/jcs.02548.

31. Phosphorylation of the AP $2 \mu$ subunit by AAK1 mediates high affinity binding to membrane protein sorting signals | Journal of Cell Biology | Rockefeller University Press, https://rupress.org/jcb/article/156/5/791/32369/Phosphorylation-of-the-AP2-subunit-by-AAK1, (accessed Aug 18, 2020).

32. Zhang, C. X.; Engqvist-Goldstein, Å. E. Y.; Carreno, S.; Owen, D. J.; Smythe, E.; Drubin, D. G. Multiple Roles for Cyclin G-Associated Kinase in Clathrin-Mediated Sorting Events: GAK in Clathrin-Mediated Trafficking. Traffic 2005, 6, 1103-1113, https://doi.org/10.1111/j.1600-0854.2005.00346.x.

33. Zhao, S.; Gao, N.; Qi, H.; Chi, H.; Liu, B.; He, B.; Wang, J.; Jin, Z.; He, X.; Zheng, H.; Wang, Z.; Wang, X.; Jin, G. Suppressive Effects of Sunitinib on a TLR Activation-Induced Cytokine Storm. Eur. J. Pharmacol. 2019, 854, 347-353, https://doi.org/10.1016/j.ejphar.2019.04.045.

34. Chu, J. J. H.; Yang, P. L. C-Src Protein Kinase Inhibitors Block Assembly and Maturation of Dengue Virus. Proc. Natl. Acad. Sci. 2007, 104 , 3520-3525, https://doi.org/10.1073/pnas.0611681104.

35. de Wispelaere, M.; LaCroix, A. J.; Yang, P. L. The Small Molecules AZD0530 and Dasatinib Inhibit Dengue Virus RNA Replication via Fyn Kinase. J. Virol. 2013, 87, 7367-7381, https://doi.org/10.1128/jvi.00632-13.

36. de Wispelaere, M.; LaCroix, A. J.; Yang, P. L. The Small Molecules AZD0530 and Dasatinib Inhibit Dengue Virus RNA Replication via Fyn Kinase. J. Virol. 2013, 87, 7367-7381, https://doi.org/10.1128/JVI.0063213.

37. Kumar, R.; Agrawal, T.; Khan, N. A.; Nakayama, Y.; Medigeshi, G. R. Identification and Characterization of the Role of C-Terminal Src Kinase in Dengue Virus Replication. Sci. Rep. 2016, 6, 30490, https://doi.org/10.1038/srep30490.

38. Panicker, N.; Saminathan, H.; Jin, H.; Neal, M.; Harischandra, D. S.; Gordon, R.; Kanthasamy, K.; Lawana, V.; Sarkar, S.; Luo, J.; Anantharam, V.; Kanthasamy, A. G.; Kanthasamy, A. Fyn Kinase Regulates Microglial Neuroinflammatory Responses in Cell Culture and Animal Models of Parkinson's Disease. $J$. Neurosci. 2015, 35, 10058-10077, https://doi.org/10.1523/JNEUROSCI.0302-15.2015.

39. Gomez, G.; Gonzalez-Espinosa, C.; Odom, S.; Baez, G.; Cid, M. E.; Ryan, J. J.; Rivera, J. Impaired FceRIDependent Gene Expression and Defective Eicosanoid and Cytokine Production as a Consequence of Fyn Deficiency in Mast Cells. J. Immunol. 2005, 175, 7602-7610, https://doi.org/10.4049/jimmunol.175.11.7602. 
40. Choi, J.; Krushel, L.A.; Crossin, K. L. NF-кB activation by N-CAM and cytokines in astrocytes is regulated by multiple protein kinases and redox modulation. Glia 2001, 33, 45-56, doi: 10.1002/10981136(20010101)33:1<45::aid-glia1005>3.0.co;2-a.

41. Rajasekaran, K.; Kumar, P.; Schuldt, K. M.; Peterson, E. J.; Vanhaesebroeck, B.; Dixit, V.; Thakar, M. S.; Malarkannan, S. Erratum: Corrigendum: Signaling by Fyn-ADAP via the Carma1-Bcl-10-MAP3K7 Signalosome Exclusively Regulates Inflammatory Cytokine Production in NK Cells. Nat. Immunol. 2014, 15, 205-205. https://doi.org/10.1038/ni0214-205b.

42. Cherian, S. S.; Agrawal, M.; Basu, A.; Abraham, P.; Gangakhedkar, R. R.; Bhargava, B. Perspectives for Repurposing Drugs for the Coronavirus Disease 2019. Indian J. Med. Res. 2020, 151, 160, https://doi.org/10.4103/ijmr.IJMR_585_20.

43. Vanommeslaeghe, K.; Hatcher, E.; Acharya, C.; Kundu, S.; Zhong, S.; Shim, J.; Darian, E.; Guvench, O.; Lopes, P.; Vorobyov, I. CHARMM General Force Field: A Force Field for Drug-like Molecules Compatible with the CHARMM All-atom Additive Biological Force Fields. J. Comput. Chem. 2010, 31, 671-690.

44. Ortega, J. T.; Serrano, M. L.; Pujol, F. H.; Rangel, H. R. Role of Changes in SARS-CoV-2 Spike Protein in the Interaction with the Human ACE2 Receptor: An in Silico Analysis. EXCLI J. 2020, 19, 410.

45. ARCHONTIS, G.; BARTELS, C.; BORESCH, S.; CAFLISCH, A.; CAVES, L.; CUI, Q.; DINNER, A.; FEIG, M.; FISCHER, S.; GAO, J. CHARMM: The Biomolecular Simulation Program.

46. Wang, J.; Wolf, R. M.; Caldwell, J. W.; Kollman, P. A.; Case, D. A. Development and Testing of a General Amber Force Field. J. Comput. Chem.2004, 25, 1157-1174.

47. Uzzaman, M.; Shawon, J.; Siddique, Z. A. Molecular Docking, Dynamics Simulation and ADMET Prediction of Acetaminophen and Its Modified Derivatives Based on Quantum Calculations. SN Appl. Sci. 2019, 1, 1437.

48. Cheng, F.; Li, W.; Zhou, Y.; Shen, J.; Wu, Z.; Liu, G.; Lee, P. W.; Tang, Y. AdmetSAR: A Comprehensive Source and Free Tool for Assessment of Chemical ADMET Properties. 2012.

49. Yoshino, R.; Yasuo, N.; Sekijima, M. Identification of Key Interactions between SARS-CoV-2 Main Protease and Inhibitor Drug Candidates. Sci. Rep. 2020, 10, 12493, https://doi.org/10.1038/s41598-020-69337-9.

50. Koulgi, S.; Jani, V.; Uppuladinne, M. V.; Sonavane, U.; Joshi, R. Remdesivir-Bound and Ligand-Free Simulations Reveal the Probable Mechanism of Inhibiting the RNA Dependent RNA Polymerase of Severe Acute Respiratory Syndrome Coronavirus 2. RSC Adv. 2020, 10, 26792-26803.

51. Jeong, G. U.; Song, H.; Yoon, G. Y.; Kim, D.; Kwon, Y.-C. Therapeutic Strategies Against COVID-19 and Structural Characterization of SARS-CoV-2: A Review. Front. Microbiol. 2020, 11, 1723, https://doi.org/10.3389/fmicb.2020.01723.

52. Hall, D. C.; Ji, H.-F. A Search for Medications to Treat COVID-19 via in Silico Molecular Docking Models of the SARS-CoV-2 Spike Glycoprotein and 3CL Protease. Travel Med. Infect. Dis. 2020, 35, 101646, https://doi.org/10.1016/j.tmaid.2020.101646.

53. Anand, K.; Ziebuhr, J.; Wadhwani, P.; Mesters, J. R.; Hilgenfeld, R. Coronavirus Main Proteinase (3CLpro) Structure: Basis for Design of Anti-SARS Drugs. Science. 2003, 300, 1763-1767. https://doi.org/10.1126/science.1085658.

54. Chen, Y. W.; Yiu, C.-P. B.; Wong, K.-Y. Prediction of the SARS-CoV-2 (2019-NCoV) 3C-like Protease (3CL pro) Structure: Virtual Screening Reveals Velpatasvir, Ledipasvir, and Other Drug Repurposing Candidates. F1000Research. 2020, 9, https://doi.org/10.12688/f1000research.22457.2.

55. Khan, R. J.; Jha, R. K.; Amera, G. M.; Jain, M.; Singh, E.; Pathak, A.; Singh, R. P.; Muthukumaran, J.; Singh, A. K. Targeting SARS-CoV-2: A Systematic Drug Repurposing Approach to Identify Promising Inhibitors against 3C-like Proteinase and 2'-O-Ribose Methyltransferase. J. Biomol. Struct. Dyn. 2020, 0, 1-14, https://doi.org/10.1080/07391102.2020.1753577.

56. Fouzia, M.; Noureddine, M.; Said, G. Study of Interaction Between Angiotensin-Converting Enzyme ACE and Diuretic Inhibitor by Molecular Modeling. Am. J. Chem. Eng. 2019, 7, 113-119.

57. Manikrao, A. M.; Mahajan, N. S.; Jawarkar, R. D.; Mahajan, D. T.; Masand, V. H.; Hadda, T. Docking Studies of Few C-3 Substituted Azapteridines as Hepatitis C Virus RNA-Dependent RNA Polymerase Inhibitors. J Comput Method Mol Des. 2011, 1, 35-45.

58. Wu, C.; Liu, Y.; Yang, Y.; Zhang, P.; Zhong, W.; Wang, Y.; Wang, Q.; Xu, Y.; Li, M.; Li, X.; Zheng, M.; Chen, L.; Li, H. Analysis of Therapeutic Targets for SARS-CoV-2 and Discovery of Potential Drugs by Computational Methods. Acta Pharm. Sin. B. 2020, 10, 766-788. https://doi.org/10.1016/j.apsb.2020.02.008.

59. Alexpandi, R.; De Mesquita, J. F.; Pandian, S. K.; Ravi, A. V. Quinolines-Based SARS-CoV-2 3CLpro and RdRp Inhibitors and Spike-RBD-ACE2 Inhibitor for Drug-Repurposing Against COVID-19: An in Silico Analysis. Front. Microbiol. 2020, 11, 1796. https://doi.org/10.3389/fmicb.2020.01796. 
60. Eckerle, L. D.; Becker, M. M.; Halpin, R. A.; Li, K.; Venter, E.; Lu, X.; Scherbakova, S.; Graham, R. L.; Baric, R. S.; Stockwell, T. B.; Spiro, D. J.; Denison, M. R. Infidelity of SARS-CoV Nsp14-Exonuclease Mutant Virus Replication Is Revealed by Complete Genome Sequencing. PLoSPathog. 2010, 6, e1000896, https://doi.org/10.1371/journal.ppat.1000896.

61. Elfiky, A. A. Ribavirin, Remdesivir, Sofosbuvir, Galidesivir, and Tenofovir against SARS-CoV-2 RNA Dependent RNA Polymerase (RdRp): A Molecular Docking Study. Life Sci. 2020, 253, 117592, https://doi.org/10.1016/j.lfs.2020.117592.

62. Pachetti, M.; Marini, B.; Benedetti, F.; Giudici, F.; Mauro, E.; Storici, P.; Masciovecchio, C.; Angeletti, S.; Ciccozzi, M.; Gallo, R. C.; Zella, D.; Ippodrino, R. Emerging SARS-CoV-2 Mutation Hot Spots Include a Novel RNA-Dependent-RNA Polymerase Variant. J. Transl. Med. 2020, 18, 179, https://doi.org/10.1186/s12967-020-02344-6.

63. Wu, F.; Zhao, S.; Yu, B.; Chen, Y.-M.; Wang, W.; Song, Z.-G.; Hu, Y.; Tao, Z.-W.; Tian, J.-H.; Pei, Y.-Y.; Yuan, M.-L.; Zhang, Y.-L.; Dai, F.-H.; Liu, Y.; Wang, Q.-M.; Zheng, J.-J.; Xu, L.; Holmes, E. C.; Zhang, Y.-Z. A New Coronavirus Associated with Human Respiratory Disease in China. Nature. 2020, 579, 265269, https://doi.org/10.1038/s41586-020-2008-3.

64. Ul Qamar, M. T.; Alqahtani, S. M.; Alamri, M. A.; Chen, L.-L. Structural Basis of SARS-CoV-2 3CL(pro) and Anti-COVID-19 Drug Discovery from Medicinal Plants. J. Pharm. Anal. 2020, https://doi.org/10.1016/j.jpha.2020.03.009.

65. Ryu, Y. B.; Jeong, H. J.; Kim, J. H.; Kim, Y. M.; Park, J.-Y.; Kim, D.; Nguyen, T. T. H.; Park, S.-J.; Chang, J. S.; Park, K. H.; Rho, M.-C.; Lee, W. S. Biflavonoids from Torreya Nucifera Displaying SARS-CoV 3CL(pro) Inhibition. Bioorg. Med. Chem. 2010, 18, 7940-7947, https://doi.org/10.1016/j.bmc.2010.09.035.

66. Jo, S.; Kim, H.; Kim, S.; Shin, D. H.; Kim, M.-S. Characteristics of Flavonoids as Potent MERS-CoV 3Clike Protease Inhibitors. Chem. Biol. Drug Des. 2019, 94, 2023-2030, https://doi.org/10.1111/cbdd.13604.

67. Jo, S.; Kim, S.; Shin, D.; Kim, M.-S. Inhibition of SARS-CoV 3CL Protease by Flavonoids. J. Enzyme Inhib. Med. Chem. 2020, 35, 145-151, https://doi.org/10.1080/14756366.2019.1690480.

68. Nguyen, T. T. H.; Woo, H.-J.; Kang, H.-K.; Nguyen, V. D.; Kim, Y.-M.; Kim, D.-W.; Ahn, S.-A.; Xia, Y.; Kim, D. Flavonoid-Mediated Inhibition of SARS Coronavirus 3C-like Protease Expressed in Pichia Pastoris. Biotechnol. Lett. 2012, 34, 831-838, https://doi.org/10.1007/s10529-011-0845-8.

69. Schwarz, S.; Sauter, D.; Wang, K.; Zhang, R.; Sun, B.; Karioti, A.; Bilia, A. R.; Efferth, T.; Schwarz, W. Kaempferol Derivatives as Antiviral Drugs against the 3a Channel Protein of Coronavirus. Planta Med. 2014, 80, 177-182, https://doi.org/10.1055/s-0033-1360277.

70. Sawikowska, A. Meta-Analysis of Flavonoids with Antiviral Potential against Coronavirus. Biom. Lett. 2020, 57, 13-22, https://doi.org/10.2478/bile-2020-0002.

71. Russo, M.; Moccia, S.; Spagnuolo, C.; Tedesco, I.; Russo, G. L. Roles of Flavonoids against Coronavirus Infection. Chem. Biol. Interact. 2020, 328, 109211, https://doi.org/10.1016/j.cbi.2020.109211. 